\title{
FACTORS INFLUENCING HONEY MARKETING IN CASE OF GIMBO WOREDA; KAFA ZONE
}

\author{
Melaku Melese Haile \\ Lecturer \\ Mizan Tepi University, Ethiopia \\ E-mail: melerasha@gmail.com
}

\begin{abstract}
This study was aimed to analyze factors influencing honey marketing efficiency in case of Gimbo woreda; kafa zone with the specific objectives of examining the factors influencing honey marketing efficiency and assessing the level of marketing channels efficiency. In order to attain these objectives the researcher used primary and secondary data by using structured questionnaire to collect data from a sample of 120 and marketing middleman's from six rural honey producing kebeles by using judgmental sampling techniques. The analysis of marketing efficiency was made by using marketing margin analysis. The assessment of marketing channels of honey show that there are four marketing participants; these include honey producers, retailers, wholesalers and consumers. Three marketing channels were identified in the study area. First channel involved selling of honey directly from producers to consumers; second channel involved selling honey from producers to retailers to consumers and third channel is ProducerRetailer - Wholesaler - consumers. The results from gross Margin analysis result reveal that beekeepers earned on average birr 1304.892 per hive as a Gross income from the sales of $15.781 \mathrm{~kg}$ of honey on average. Based on the findings this research recommended policy remedies in order to improve honey marketing efficiency by facilitating reliable market outlet for the beekeeper, establishing marketing organizations (cooperatives) to allow farmers to sell their products at competitive product price. The findings suggests that, effective market service has to be established to provide accurate and timely market information to farmers and traders on current honey demand and prices at national and regional levels. Emphasis should be given to improve producers and marketing middleman's capacity, through offering credit and other services to improve in the marketing of honey.
\end{abstract}

Keywords: Honey, Marketing, Marketing Channel.

\section{INTRODUCTION}

Ethiopia is the biggest honey producer in Africa and 10th biggest honey producer all over the world. Moreover, significant quantity of wax is produced within the country. Ethiopia is fourth beeswax producer and tenth honey producer in the world. Having high number of bee colonies and excess sources of vegetation; Ethiopia is the leading producer of honey and beeswax in Africa. Ethiopia produces around $23.6 \%$ and $2.1 \%$ of the overall Africa and World's honey, respectively (Girma, 2008).

An efficient, integrated, and responsive market is vital for optimum allocation of agricultural resources in order to stimulating farmers to increase output. Without having suitable marketing conditions, the possible growth in output, rural incomes and foreign exchange resulting from the introduction of improved production technologies could not be operational (Jones, 1992). 
Although SNNPR, especially Kafa zone is believed to have dense woodland and varied types of vegetation predicted to be potential source for beekeeping activities so a long way there is no enough and dependable information on honey production and marketing system.

Despite the excessive honey production potential in Kafa zone especially Gimbo woreda, there is many factors those determines honey production and its marketing. Therefore, this study focusses on assessing determinants of honey marketing issues of honey producers and traders in Gimbo woreda; Kafa zone, SNNPR.

\section{General Objective of The Study}

\section{OBJECTIVES OF THE STUDY}

The general objective of the study was to investigate the major Determinates of honey marketing efficiency in case of Gimbo woreda; kafa zone, SNNPR.

\section{Specific Objectives}

- To examine factors influencing honey marketing efficiency.

- To assess the level of marketing channels efficiency

\section{THEORETICAL AND EMPIRICAL LITERATURE REVIEW} Marketing Systems of Honey

This aspect is considerably undermined by many people who feel that the focus should be on production and then simply selling the outcome of production to customers. Certainly production is a very important aspect, especially in the case of organic honey, where production procedures and processing have to be maintained. But, equally important, marketing has to be considered and given the same importance (Hilmi, 2005).

Three principal channels were identified in the marketing of honey. Tej house are one of the honey buy acting as market channel; in addition to honey processing and exporting channel and beeswax channel. Those channels are interrelated which shows absence of structured marketing channel and no proper relationship between the actors. All most all of honey product goes Tej house for "Tej" making purpose. Honey producers straightly sell their honey to local honey retailers (merchant or cooperatives) at kebele or zonal levels, which directly distribute the honey to "Tej" houses in their neighborhoods or distribute it to the whole sellers(BeyeneTadesse, 2007)

The constraints to marketing of honey in Ethiopia are low and discouraging price of honey in local markets, lower quality of products, absence of organized market channel, transportation problem. Presentation of quality honey is generally poor. Most honey come to market is unextracted, unstrained and poorly managed (GezahegneTadesse, 2001).

It has been observed that in the SNNPR the marketing system of honey has many problems. The lack of grading systems that does not encourage farmers to produce high quality products, thus, the price of honey changes widely based on the good will of buyers (Kerealem Ejigu, 2009)

\section{Description of the Study Area}

\section{DATA AND METHODOLOGY}

Kafa zone's administrative town - Bonga is located at $449 \mathrm{~km}$ southwest of Addis Ababa (capital city of the country). Gimbo Woreda is located $12 \mathrm{~km}$ away from Bonga town. The area is known by its dense natural forest with diverse tree and wild life species (Figure 1). 


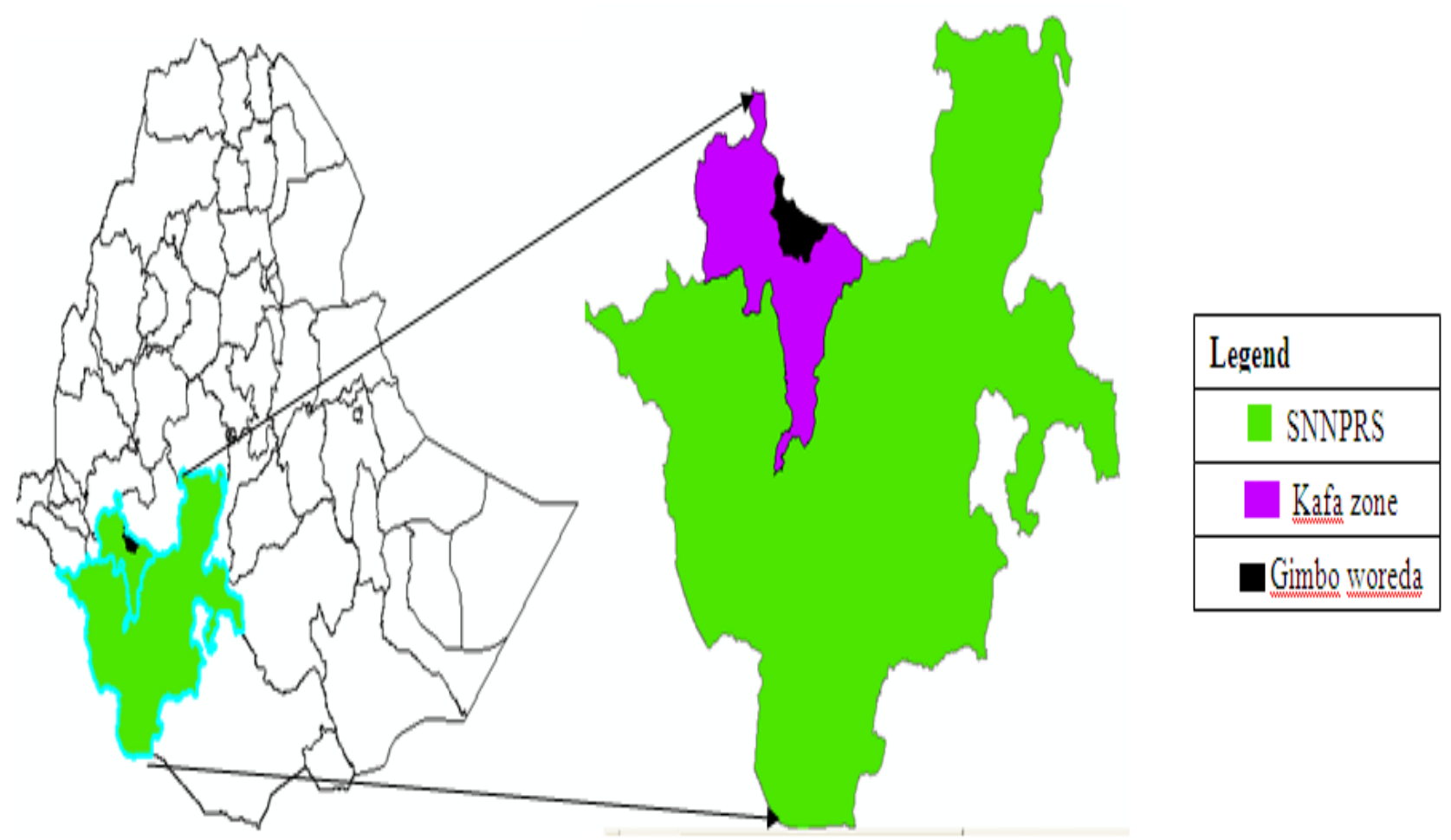

\section{Research Design}

Figure 1. The Study Area

The research design for this study was a cross-sectional. In order to address the stated objectives both primary and secondary data was used in this research. Primary data were collected using questionnaire form honey producers and traders.

Controllable sample of dependable and knowledgeable honey producers marketing middlemen was selected purposively in order to assess marketing efficiency.

\section{Distribution of Respondents in Each Kebeles}

Table 1. Distribution of respondents in each kebele

\begin{tabular}{|llcc|}
\hline Kebele of respondents & Freq. & Percent & Cum. \\
\hline Tula & 13 & 10.83 & 10.83 \\
Michit & 21 & 17.50 & 28.33 \\
Woka Araba & 12 & 10.00 & 38.33 \\
Yeyibito & 24 & 20.00 & 58.33 \\
Kuti & 23 & 19.17 & 77.50 \\
Charaba & 27 & 22.50 & 100.00 \\
Total & 120 & 100.00 & \\
\hline
\end{tabular}

Source: Own survey 2019

\section{Data Analysis and Estimation Techniques}

In order to compete and analyze marketing efficiency the researcher used Marketing Margin measures. 


\section{Marketing Margin}

Marketing margin describe price differences between other points in the marketing chain, for example between producer and wholesale, wholesale and retail, prices (Scarborough, 1992).

Total gross marketing margin (TGMM)

$$
T G M M=\frac{\text { Endbuyer price }- \text { First seller price }}{\text { End buyer price }} * 100
$$

Producers share of gross margin are calculated as:

$$
G M M p=\frac{\text { End buyer price }- \text { Total Gross Marketing margin }}{\text { End buyer price }} * 100
$$

The Net Marketing Margin (NMM)

$$
N M M=\frac{\text { Gross margion-marketing cost }}{\text { End buyer price }} * 100
$$

\section{RESULTS AND DISCUSSION \\ Socio-Economic Characteristics of Honey Traders Honey Marketing Participants and Marketing Channels}

In this study, different market participants were identified in the exchange functions between producer and final consumer of honey. Producers sell their honey to different buyers involved in honey marketing in the districts. Even though, each participant was involved in different activities (Retail, wholesale, consumption and assembly), based on major activity undertaken, the sampled market participants were categorized into different categories.

\section{Participants in Honey Market}

In this study, different market participants were identified in the exchange functions between producer and final consumer of honey. Producers sell their honey to different buyers involved in honey marketing in the districts. The market place/form that is the closest to the residence of the farmers is the first preferred to selling their product in order to minimize transportation costs. Market participants in the study areas include: retailers, wholesalers, and final consumers including "Tej house". Even though, each participant was involved in different activities (wholesaling, retailing and consumption), based on major activity undertaken, the sampled market participants were dominated by consumers specially those "Tej" makers $(50 \%)$.

Table 2. Distribution of participants in honey market and average quantity of honey they buy and sale per month

\begin{tabular}{llcrcc}
\hline Participants & Freq. & Percent & cum. & quantity bought & quantity sold \\
\hline Retailers & 3 & 30 & 30 & $101.67 \mathrm{~kg}$ & $68.67 \mathrm{~kg}$ \\
Wholesalers & 2 & 20 & 50 & $215 \mathrm{~kg}$ & $145 \mathrm{~kg}$ \\
Consumers & 5 & 50 & 100 & $114.6 \mathrm{~kg}$ & \\
Total & 10 & 100 & & & \\
\hline
\end{tabular}

Source: Own survey, 2019

\section{Honey Marketing Channels}

According to (Mendaza, 1995) marketing channel is the sequence of intermediaries through which product passes from producers to consumers. Dou to poor development of infrastructure like Roads, communication facilities and market institutions in the study areas limited the range of 
marketing functions and services and restrict sales to the nearby market that are dominated by retailers. Poor infrastructure coupled with low quality of honey form a major obstacle to the marketing functions and limits the involvement of market intermediaries, which resulted into poor development of marketing channel for honey.

More often, farmers transport honey to the markets either by carrying or by using donkeys, and sometimes sell directly to local traders (local retailers) at the farm gate or in the market, or directly to wholesalers.

Through the network of marketing channel honey moves from producer to consumer are either processed or unprocessed. Few and poorly developed honey market institutions are not able to satisfy the growing demands of consumers. This indicates unsophisticated honey market structure.

In order to identify how honey moves through various market channels, it is necessary to identify the roles of various market participants involved. Survey showed that there were three marketing channels of honey in the area.

- Producer - consumer; consumers purchased honey directly from producers.

- $\quad$ Producer - Retailer - consumers; consumers purchased honey from retailer.

- $\quad$ Producer - Retailer - Wholesaler - consumers; consumers purchase honey from wholesaler including (kafa organic honey supplying union (KFOH) those buy honey from beekeepers as a wholesaler and sell to a company and consumers). KFOH union resells the honey to both consumers as processed packed Honey in small containers to local market and exports to foreign market.

As depicted on the Figure 4: 17.50\% the honey product passes from the producer to the retailer, $37.50 \%$ from producer to wholesaler and $45 \%$ from producer to consumer directly.

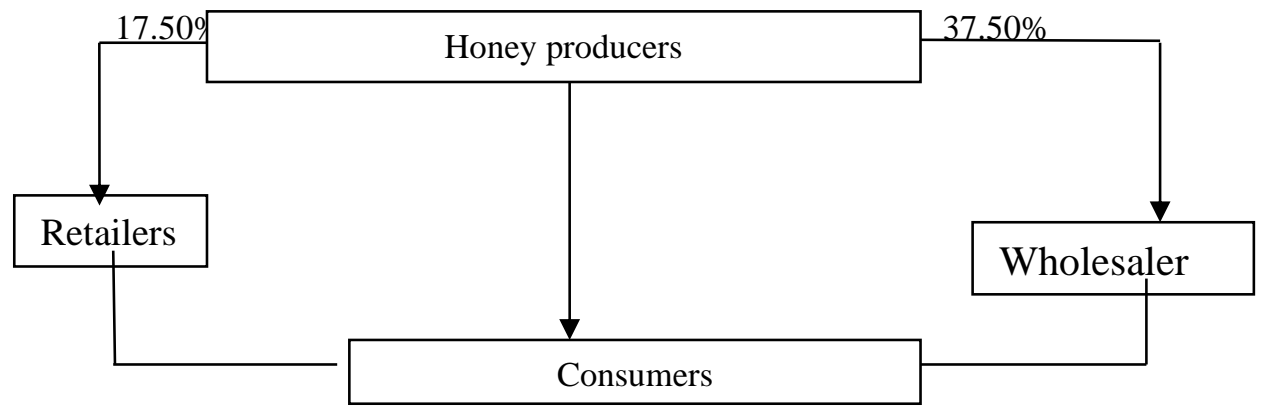

Figure 2. Marketing channels of honey

Source: Own survey result 2019

\section{Purchasing and Selling Price of Honey in Birr Per Kg at Different Market Channel}

In the study area the price of honey can vary with not only seasons but also it varies from one market channel to other market channel. The average selling prices of honey in the producers market are lower than retailer's price and wholesaler's price. Table 3 shows average purchasing and selling prices of honey in different market channel. 
Table 3. Average purchase and sales prices of honey in different market chain in Birr at year 2019

\begin{tabular}{lll}
\hline Market channels & Purchase price & Sales price \\
Producers & 0 & 62.25 \\
Retailers & 65 & 118.33 \\
Whole sellers & 72.5 & 130 \\
Consumers & 93 & - \\
\hline
\end{tabular}

Source: Own survey 2019

\section{Factors Governing the Price of Honey}

The price of honey in the study area was reported to vary depending on seasons of the year, color, taste of the honey, and purity (Table 4). According to interviewed respondent, the most demanded honey was light (white) in color, sweet in taste and pure. Honey was considered to be pure if it had fewer amounts of impurities (wing of honeybees, wax, dead adult bees and brood). Majority of the respondents $(50 \%)$ declared that quality of the honey (honey color and taste) is most important determining factors for the selling price of their honey and the remaining $30 \%$ and $20 \%$ respondents said that season of the year and distance from the market respectively can affects the price of honey in the study area.

Table 4. Percentage of factors governing the price of honey in the study area

\begin{tabular}{ll}
\hline Factors affecting price of honey & percentage of respondents \\
\hline Quality (Colors and taste of the honey) & 50 \\
Seasons of the year and & 30 \\
Market distance & 20 \\
Total & 100 \\
\hline
\end{tabular}

Source: Own survey, 2019

\section{Average Financial Capital of Sample Honey Traders and The Source Capital}

Table 5 shows that average initial and current working capital of honey traders during the survey period was estimated to be Birr 8130 and Birr 12500, respectively. Moreover, as it was indicated from survey data the current working capital of honey traders was greater than their initial working capital and the initial and current working capital of the honey trades varies from Birr 2800 to 13200 and Birr 5000 to 20000, respectively. With regard to the sources of working capital, 60 percent and 40 percent of honey traders reported that their source of working capital was own saving and credit respectively. 
Table 5. Financial capital of sampled honey traders and the source of capital

\begin{tabular}{llllcc}
\hline Initial capital & frequency & percentage & working capital & frequency & percentage \\
$1000-5000$ & 2 & 20 & $1000-5000$ & 1 & 10 \\
$5001-10,000$ & 6 & 60 & $5001-10,000$ & 2 & 20 \\
$>10000$ & 2 & 20 & $>10,000$ & 7 & 70 \\
$\quad$ Total & 10 & 100 & & & \\
Source of capital & & & & \\
Own saving & 60 & & & \\
Both saving and Credit & 40 &
\end{tabular}

Source: Own survey, 2019

\section{Marketing Performance and Gross Margin Analysis}

This study tried to determine the level of market efficiency by evaluating costs and prices of honey at different marketing middlemen. Gross margin were calculated and used in assessing measuring market efficiency. In marketing margin analysis the purchase price and selling price of honey at different marketing middlemen was considered.

\section{Marketing Participants Cost and Benefit Analysis}

Table 6 Indicates different types of cost related to production and marketing of honey producers, retailers, wholesalers and consumers. The survey data of honey producers shows that average cost per hive including the transaction cost are birr 199.06 and birr 13.42 per $\mathrm{kg}$ of honey they produces $15.78 \mathrm{~kg}$ of honey per hive and sell by average price of Birr 75.3 per $\mathrm{kg}$ which indicates that they can receives on average Birr 1304.892 as a Gross income and Birr 1105.831 as net income per hive. They can sell their honey to different market participants with different price. Those market participants are retailers, wholesalers and consumers and their average purchase price from producers are Birr 62.31, 75.28 and 90.88 per $\mathrm{kg}$. This shows that if producer sells to consumers directly they can get high price.

The marketing data shows that marketing middleman's (retailers, wholesalers and consumers) in the study area can purchase on average $101.6 \mathrm{~kg}, 215 \mathrm{~kg}$ and $114.6 \mathrm{~kg}$ by the average price of Birr 65, 72.5 and 93 respectively. The average cost of retailers and wholesalers including cost of honey purchase, Transportation, processing, labor, house rent, Tax and other miscellaneous expenses are Birr 79.47 and Birr 100.2 per kg of honey and their average selling price are birr 118.33 and 130 per kg. These results show that the selling price of honey is higher than purchase price because selling price includes purchase price, costs and the profit. They can earns the total profit of birr 4387.19 and 10297.3 on average and the consumers loss on average birr 15.761 per $\mathrm{kg}$ of honey if they purchase from retailers and wholesalers. The final consumers incur total cost which includes purchase price, transportation cost and transaction cost of Birr108.76.

The result shows that return earned by producers from sells of honey is very low when compared to retailers and wholesalers. Producers average selling price of honey to retailers, wholesalers and consumers are birr 62.31, 75.28 and 90.88 respectively. By selling to consumers producers gets higher price compared to selling to retailers and wholesalers. The average selling price of retailers and wholesalers are birr 118.33 and 130 respectively. By purchasing from producers consumers buys with lower price compared to purchasing from retailers and 
wholesalers. This is due poor development of roads, communication facilities and market institutions in the rural areas which limited the range of marketing functions and services that forces producers sell their honey to the nearby market and local traders with low price and consumers to purchase from retailers and wholesalers with higher price.

Table 6. Marketing participants cost and benefit analysis per $\mathrm{kg}$

\begin{tabular}{llccc}
\hline $\begin{array}{l}\text { Marketing } \\
\text { middleman's }\end{array}$ & $\begin{array}{l}\text { average cost including } \\
\text { purchase price in birr }\end{array}$ & $\begin{array}{l}\text { average quantity } \\
\text { sold in kg }\end{array}$ & $\begin{array}{c}\text { average } \\
\text { Selling price }\end{array}$ & $\begin{array}{l}\text { average } \\
\text { return }\end{array}$ \\
\hline Producers & 13.42 & 15.781 & 75.3 & 1304.892 \\
Retailers & 79.47 & 68.66 & 118.33 & 4387.19 \\
Wholesalers & 100.2 & 145 & 130 & 10297.3 \\
Consumers & 108.76 & 0 & 0 & - \\
\hline
\end{tabular}

Source: Own survey 2019

\section{Marketing Margin}

Marketing margins are different among each marketing actors or participants in different channels.

- Producer - consumer; consumers purchased honey directly from producers.

- Producer - Retailer - consumers; consumers purchased honey from retailer.

- Producer-Wholesaler-consumer; consumers purchased honey directly from wholesaler.

Table 7. Marketing margins of traders in different marketing channels

\begin{tabular}{llll}
\hline Marketing margins & Channel I & Channel II & Channel III \\
\hline Producer price & 75.3 & 62.31 & 75.28 \\
End buyer price & 90.88 & 118.33 & 130 \\
Total Gross marketing margin & $17.14 \%$ & $45.04 \%$ & $44.37 \%$ \\
Gross Marketing Margin & $85.23 \%$ & $87.77 \%$ & $78.69 \%$ \\
Net marketing margin & $68.09 \%$ & $42.73 \%$ & $34.32 \%$ \\
\hline
\end{tabular}

Source: Own Survey results

The computed marketing margin among different actors and channels indicated, the total gross marketing margin (TGMM) of honey is highest in Channel II and III compered to channel I. Of all honey traders, retailers (channel II) get the highest gross marketing margin of consumers' price. In general, producers share in consumer price is low in channel II and channel III compared to channel I which shows that both producers and consumers loss as the number of marketing channel increases. Small marketing margin, however, is not always equated with efficient performance in marketing functions.

\section{CONCLUSION}

The objective of this research is identifying major determinants of honey marketing efficiency. Gross Margin analysis was used to analyze honey market efficiency. Result of Gross Margin 
analysis reveal that beekeepers earned on average birr 1304.892 as a Gross income from the sales honey. Hence honey production is a profitable activity to be undertaken by encouraging beekeepers to increase number of modern beehives. The assessment of marketing channels of honey show that there are four marketing participants; these include honey producers, retailers, wholesalers and consumers. Three major marketing channels were identified in the study area. First channel involved selling of honey direct from producers to consumers; second channel involved selling honey from producers to retailers to consumers and third channel is Producer Retailer - Wholesaler - consumers.

The findings of this study and their subsequence recommendations will form important bases for various development sectors like policy makers, central and local government and academicians for making rational decision to improve marketing efficiency. Based on the results of this study the following measures are recommended.

\section{RECOMMENDATION}

The infrastructure supporting production, processing and the marketing of honey product is poorly developed. Therefore, expansion of infrastructure like road, telecom and electric power should be improved to improve honey marketing efficiency.

Most of households lack adequate financial resources to invest on improved honey production technologies, storage, processing facilities and packaging. Thus, proper market link \& credit facility should be available to individuals who are willing to be organized and involved in the production, collection, processing, packing and marketing of honey products. Reliable market outlet for the beekeepers marketing organizations (for e.g., cooperatives unions) should be established to allow farmers sell their products at competitive product price.

Remoteness of most of honey producers from demand areas (town) is one of the constraints to honey marketing in study area, which resulted into inadequate marketing link between the rural producer and the urban consumer. This missing link can be reduced through institutional arrangement such as cooperative structures and creating asymmetries and easily available information access and collective action, pooling resources and lowering the unit cost of transactions are needed. Provision of financial capital, such as financial income from different sources and credit (loan) found to stimulate honey market participation.

The findings suggests that, effective market service has to be established to provide accurate and timely market information to farmers and traders on current honey demand and prices at national and regional levels. In this arena, emphasis should be given to improve producers and marketing middleman's capacity, through offering credit and other services to improve effective production and marketing of honey.

\section{REFERENCES}

BeyeneTadesse. (2007). Ensuring small scale producers in Ethiopia to achieve sustainable and fair access to honey markets. Paper prepared for International Development Enterprises (IDE) and Ethiopian Society for Appropriate Technology (ESAT). Addis Ababa, Ethiopia.

GezahegneTadesse. (2001). Beekeeping (In Amaharic). Addis Ababa, Ethiopia: Mega Printer Enterprise.

Girma. (2008). Non-wood forest products in Ethiopia. EC-FAO Partnership Programme. Addis Ababa.Ethiopia. 
Hilmi, M. (2005). The marketing of organic honey . [http://www.skamberg.com/ honey]Site visited on $14 / 4 / 2007$.

Jones, O. (1992). Marketing staple Foods in Tropical Africa. London,: Cornell University Press.

Kerealem Ejigu, T. a. (2009). Constraints and prospects for apiculture research and development in Ethiopia. Addis Ababa.: Institute of Biodiversity Conservation and Research Technical Report No.1 .

Mendaza, M. a.-g. (1995). pricing behavior in Philippine Corn market Implication for food marketing efficiency. Philippine: IFPRI Research.

Scarborough, V. a. (1992). Economic Analysis of Agricultural market: A Manual Marketing Series 5. Chatham. UK: Natural Resource Institute.

\section{APPENDICES}

\section{Appendix A: Normality test}

kdensity stands for kernel density estimate

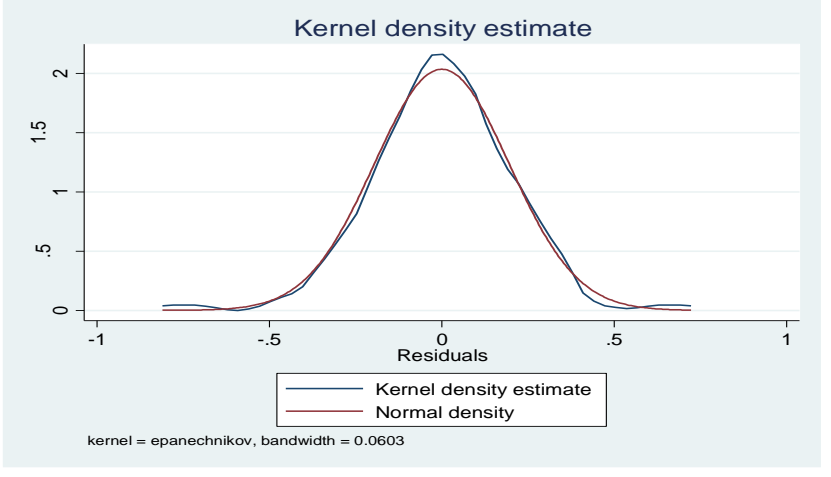

\section{norm res}

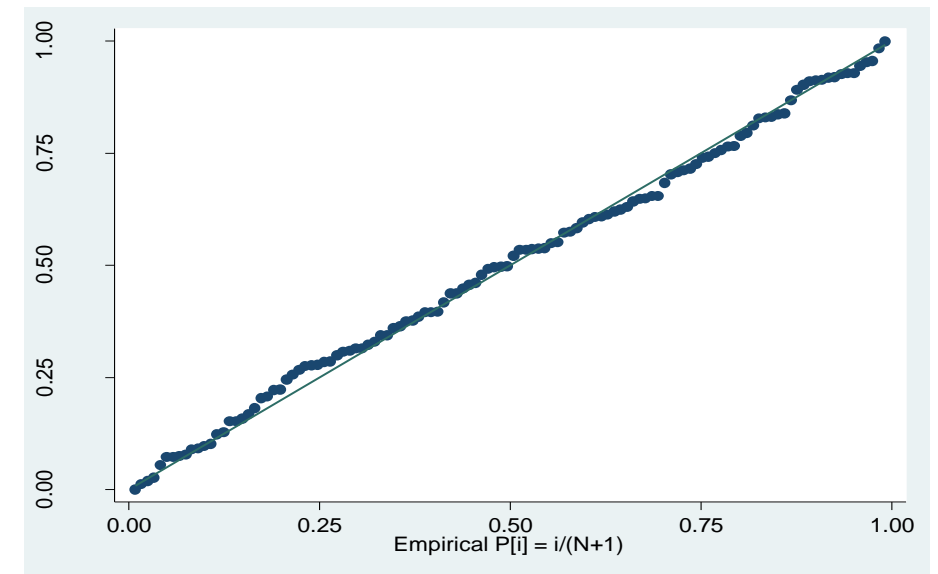

Test for Model Specification 


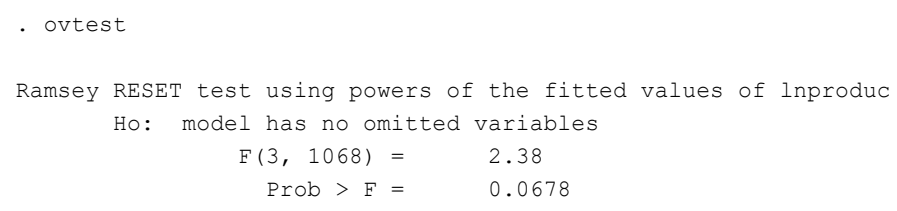

\section{Copyrights}

Copyright for this article is retained by the author(s), with first publication rights granted to the journal. This is an open-access article distributed under the terms and conditions of the Creative Commons Attribution license (https//creativecommons.org/licenses/by/4.0). 